\title{
STRONG STRUCTURATION THEORY AND MANAGEMENT ACCOUNTING RESEARCH
}

Lisa Jack'

Summary Strong structuration theory is a recent development in social theory that, among other attributes, makes the gap between ontological concepts and empirical research easier to negotiate. Giddens' structuration theory is a developed ontology-in-general explaining at an abstract level how structure and agency are interrelated, being a duality in which neither can exist without the other. Strong structuration is a development of structuration theory that retains duality of structure but has a greater sense of ontology-in-situ (that is, a concern with social processes and events at particular times and places) to counteract the overly abstract and philosophical nature of Giddens' work. In this essay, I set out three reasons why I believe that strong structuration theory is particularly suited to qualitative empirical research in management accounting. These are that it encourages and reminds researchers to use up to date scholarship from other disciplines in their research; that it refocuses research on agency and the intended and unintended effects that individual people have on structures; and that it encourages research design that have the intention of building new theoretical insights. A review of the small body of accounting research that has so far used strong structuration theory shows that researchers are using innovative approaches, based on Stones' (2005) and later work, to investigate the relationships between different actors and their knowledge of the contexts which they inhabit to understand why accounting is done in the way it is, and the extent to which change is possible. The next step in this area of research is to consider the concept of active agency within the theory more closely, and in particular, to examine communication in management accounting as active agency.

Keywords: strong structuration theory, management accounting, empirical research

'e-mail: lisa.jack@port.ac.uk - University of Portsmouth

- DOI: http://dx.doi.org/10.14392/asaa.2017100205

— Paper received: 09 January 2017. Paper accepted: 13 March 2017. 


\section{INTRODUCTION}

idden's structuration theory has been used in management accounting research since the mi-

d-1980s, during part of a fertile period that produced what Mattessich $(2008$, p.206) calls 'the critical-interpretative perspective [which] may be the most prominent British contribution to modern accounting research and methodology'. Baxter and Chua (2003, p.100) recognised that 'Giddens' theory of structuration has created a small but distinctive contribution to alternative management accounting research'. By 2011, Englund, Gerdin and Burns were able to review some 65 papers that used structuration theory in the accounting field. However, structuration theory has also developed outside of the accounting discipline. Over the last 30 years, the work of Giddens has been critiqued and refined by social theorists and researchers in many disciplines. Bryant and Jary (2011, p.444) claim that "In [...] Structuration Theory, Stones (2005) sets out the most important development of structuration theory since Giddens himself turned to other matters". Stones (2005) provides what he terms a 'strong structuration theory' that synthesises the criticisms and developments of the theory to create a stronger version particularly aimed at facilitating theoretically informed empirical work. For example, Giddens' structuration theory is a developed ontology-in-general explaining at an abstract level how structure and agency are interrelated, being a duality in which neither can exist without the other. Strong structuration is a development of structuration theory that retains duality of structure but has a greater sense of ontology-in-situ (that is, a concern with social processes and events at particular times and places) to counteract the overly abstract and philosophical nature of Giddens' work (Stones, 2005).

There is growing interest in Stones' work in the accounting and management disciplines and in this essay, I am going to explore why strong structuration theory is being adopted by a number of researchers in Europe and Australia. A recent special issue in the Accounting, Auditing and Accountability Journal (Vol. 29 Issue 7, 2016), brings together the work of Rob Stones - who is a British social theorist now based in Australia - and the work of early career researchers who are exploring the extent to which the theory can be used to create innovative empirical studies in management accounting. I am going to set out three reasons why I believe that strong structuration theory is suited to research in management accounting, before discussing current work using the theory and its potential to provide new directions in empirical research and theoretical development in the field of management accounting.

\section{REASON 1: THE IMPORTANCE OF USING UP TO DATE SCHOLARSHIP IN MANAGEMENT ACCOUNTING RESEARCH}

Although Giddens'structuration theory has been used for some 30 years in management accounting research, its full potential has not yet been exploited (Coad, Jack and Kholeif, 2015; Englund and Gerdin, 2014; Englund, Gerdin and Burns, 2011). One reason for this is that strong structuration theory is most often used as a framing or sensitising device, often in conjunction with other social theories. In other words, there is an absence of critical evaluation of the theory in existing papers. Englund et al (2011) do identify the work of Coad and Herbert (2009), and of Jack and Kholeif $(2008 ; 2007)$ as being critical but do not explore the fact that these papers use strong structuration theory (Coad et al, 2015). Before 
we can investigate the significance of this, a little history and explanation of both Giddens' and Stones' versions of the theory is required. Before we go further, we also need to consider how social theories are used in management accounting research and indeed, most social theory research, as this is invariably problematic (Jack, 2017).

Giddens developed structuration theory throughout the 1970s, and its fullest expression is found in his book 'The Constitution of Society' (1984). At its heart, structuration theory is an explanation of how structure and agency are related in the development of social behaviour. Societies take the shape they have because of the interplay between social structures and human actions. The study of social structure has been central to socio-economic thought over centuries and structures can be seen as existing apart from people. Structures and systems persist because people comply, conform and act in ways that maintain social norms and expectations. The extent to which human agency (where people have the ability to influence as well as act) is often treated as a separate area of study. By the 1970s, structures were seen as having functional properties, and how people negotiated social structures, their knowledge and the way they acted was becoming of central importance. Sociologists were moving towards analyses based on the social construction of knowledge (Berger and Luckmann, 1967) and the meanings people ascribed to their actions. Sociological study appeared to be divided between Marxist analyses of capitalism and other macro-level institutional phenomena on the one hand, and ethnographic micro-level analyses on the other. Giddens was concerned with getting back to an ontological understanding of social reality that integrated macro and micro-levels of analysis (Ritzer, 2007). What he was interested in were 'social practices that recur in a patterned way' over time and space (Ibid, p.168). Micro-macro and agency-structure are continua, and cannot be conceived as being separate. The central tenet is the duality of structure where'all social action involves structure and all structure involves social action' (Ibid.)

This emphasis on social practices and recursive, reflexive patterns leads us to the question of why some practices become institutionalised and why they might become difficult to change. Giddens proposed that within these institutions, practices and systems simultaneously consisted of three modalities. $\mathrm{He}$ identified these as signification, legitimation and domination. One way of seeing this is to think of rules and routines being always present with norms and sanctions, and with the exercise of power by agents to ensure that the patterns are maintained. From these concepts, we can begin to see why structuration theory holds so much promise for accounting researchers. It facilitates the investigation of meso-levels of analysis - organisations, groups - and the systems within them. We can examine accounting as a set of social practices within and across organisational boundaries. As Roberts and Scapens (1985, p.445) explained in the first paper in accounting based on The Constitution of Society:

It is the centrality of the notion of practice or practices and in particular, the analysis of the interdependent character of practices with the concepts of "system" and "structure"that makes Giddens' work an attractive framework for understanding the significance of accounting in the production and reproduction of organisational life.

They conclude by considering the central role of the use of information by accountants to shape organisational life and the sense of 'the tenuous and recursive nature of the relationship between the image or picture produced in the Accounts, and the flow of organisational events and practices that the Accounts purport to record' (Ibid, p.454). Accountants need to either consider improving the information 
they produce, or to think more deeply about how the information is actually used in a management context, and the way in which they work with others in an organisation. To what ends are the legitimation and power of various actors - their position - driving communications rather than a fair representation of financial reality? These are the fundamental questions behind much interpretative-critical research, and the analysis is facilitated by Giddens' concepts of the modalities of structuration and institutionalisation.

Structuration theory, then, allows researchers to consider questions of why accounting practices become institutionalised and taken-for-granted and what might be needed to allow them to change. In essence, it is about the influential actions of certain actors and the practices they are able to embed in organisations, from within or from outside. We can ask why certain budgetary processes are adopted in one organisation, and why the same practices are found or not found in other organisations. The implications of change for individuals, teams, organisations, professions and society itself could be established through this type of study, depending on how it is positioned. Structuration theory is one way of seeing accounting in its social and organisational context (Baxter and Chua, 2003; Hopwood and Miller, 1994). Englund and Gerdin (2014) provide an excellent and critical review of work in this field to date.

However, there are a number of issues with how Giddens' structuration theory is used in practice and indeed, with how interpretative-critical case studies are constructed in accounting and management disciplines, which I will cover in reasons 2 and 3 below. Repeating observations that I have made elsewhere (Jack, 2017), the essential problem with accounting research using structuration theory is that it is almost wholly based on accounting papers from the 1980s and 1990s, and on Giddens (1984). This is a problem because structuration theory, as indicated in the introduction, is not confined to Giddens' work, and certainly is not confined to its translations into the accounting field. Strong structuration theory is a development that synthesises and absorbs criticisms and refinements of Giddens' theory. Stones $(2015 ; 2005 ; 1996)$ also tackles a wider issue of how to apply social theory in empirical research, how to bridge the gap between ontological concepts and empirical research (Stones and Jack, 2016). Coad et al $(2015$, p.168) comment that they'agree with the observations made by Englund et al. (2011) and Englund and Gerdin (2014) that there has been a relative reluctance on the part of the community of accounting academics to engage critically with structuration theory, and that most studies in the accounting literature focus primarily on structural analysis to the detriment of considerations of agency'. This leads me to the second reason why strong structuration theory offers an innovative approach to management accounting case study research.

\section{REASON 2: RE-FOCUSING ON AGENCY}

The central tenet of duality of structure, that structure and agency are inseparable, is problematic for practical research purposes. Giddens' resolution was to employ methodological bracketing, which means that researchers have two choices; either to carry out an 'institutional analysis' that means focusing on structural practices, leaving agents' conduct to one side, or focusing on strategic conduct analysis, and leaving structures to one side (Stones, 2005; Giddens, 1984). In practice, especially in accounting research, there is a predominance of institutional analysis, looking at how systems and practices become embedded and the underlying reasons and issues (Coad et al, 2015; Roberts, 2014; Englund and Gerdin, 2014). Even in Giddens' work, strategic conduct analysis is underdeveloped and he worked mostly on macro-level, more abstract analyses of the institutions of public life despite examples of how the theory applied to micro-level cases (Giddens, 1984). A result of this is that the epistemological aspects of 
structuration theory are one of its weaknesses, along with a tendency to treat agents as homogenous groups across time and space (Cohen, 1991).

In Stones and Jack (2016, p.1146), Stones recounts how he was drawn to structuration theory at an early stage of his analysis of British government actions on monetary policy in the 1970s. He says:

I found that when I wanted to look at real life flesh and blood people, these macro theories didn't help me, so I was drawn to Giddens at that stage. What structuration theory allowed me to do was to link really macro historical political forces to flesh and blood people around tables ... and in the bar, in cafés, wherever - at home, soliloquies, as shown in ... memoirs as well. Actually, it took me a while to realise that Giddens wasn't using his theory in the same way that I was using it. I'd already started adapting structuration theory to empirical issues in a way that Giddens wasn't.

The question missing from many structurally based studies in accounting is what is the role of people, individual accountants, in creating and maintaining structures? What happens in daily conversations, decision making, and working life that produces and reproduces practices? How do people draw on their knowledge to act recursively and reflexively?

Stones (2005) developed the methodological bracket of strategic conduct analysis and placed the agent at the focal point of the research (the'agent-in-focus'). He proposed that researchers should look at an agent's (or cluster of agents') analysis of their own context and their own conduct (termed an agent's context analysis and agent's conduct analysis, rather than strategic conduct analysis). In doing so, we are able to understand how agents understand themselves, their situation and the structures and other agents around them. In addition, we aim to understand the agent-in-focus's understanding of other agents' contexts and conduct, and how it might affect their own actions. This is what Giddens termed the double hermeneutic in research: understanding how we as researchers understand how agents come to understand and act. The aim is to explain active agency - will the agent in focus reproduce current structures, patterns and practices or choose to do otherwise, and with what outcome?

It is this analysis of active agency arising from an agent's knowledge of context and conduct that is the strength of strong structuration theory, and which provides new directions for empirical data collection and analysis. To understand how agents use their knowledge in active agency, Stones (2005) developed the concept of the quadripartite nature of structuration. He proposed that agents will act based on their internal structures: general dispositions (or habitus), the knowledge that they have of themselves, and conjuncturally specific (or situational) knowledge of their role, position and external structures and agents.

This split into internal and external structures is contentious (Englund and Gerdin, 2016), but it addresses a long standing disagreement between structuration theorists and critical realists, or between duality and dualism. There may be moments or points at which structure and agency are asynchronous in terms of how agents evaluate knowledge. It helps the analysis of those situations where people might be able to alter their own or others' internal structures whilst external structures stay ostensibly the same. For example, we could envisage that prescribed day to day budget routines might change within a team or organisation but the actual universal practice of budgeting might remain unchanged. It allows for a nuanced understanding of change and stability within case study research. In acting, agents know more or less what they can and cannot change, where resistance is feasible and where influence needs to be exerted. Thus in accounting, active agency can be seen as the use of persuasive communication, decision-making, and the use of arguments. It moves away from the report or artefact or event, towards 
the analysis of processes, thoughts, communications, motivations and intentions. The study of outcomes becomes the study of intended and unintended consequences as active agency reproduces or changes existing structures.

Strong structuration theory changes the way in which we might look at accounting practices, by viewing them through the minds of accountants rather than their external manifestations of controls and artefacts. Asked if he was surprised that accounting and management researchers were early adopters of strong structuration theory (seeing it as an adaptive innovation), Stones replied:

\begin{abstract}
it feels to me as if at least two things are going on here. One is that accounting and management is at a meso-level, and the other is about precision, I think.... in accounting and management... precision matters and real knowledge matters, and whether your knowledge is adequate or inadequate matters, and even though we've not quite got there yet, I think there's a sense in which knowing about the status and the adequacy of knowledge is probably more important for the sort of world you're in than it is for many of today's sociologists. (Stones and Jack, 2016, p.1150)
\end{abstract}

How this type of research and analysis might be developed can be seen in the recent publication by Stones (2015) Why current affairs needs social theory. In Chapter 3, he maps out - using a fictional example - the actors, knowledge, actions and relationships within a contextual field all the things that need to be analysed by focal agents before and whilst they act. In this chapter, he digs down into the 'how, what, why, where and when' of empirical analysis (Parker, 2008) to produce a detailed, dynamic account of the effects of communication and the realities of political actions.

This is an area that still needs to be developed in accounting research. Initially, strong structuration theory was used to analyse the nature and presence of external and internal structuring, and the institutionalisation of accounting practices, using the quadripartite nature of structuration as a model. However, it is moving towards being agents' context and conduct analysis, as described further below. This calls for a different approach to research design, which brings us to reason 3 for using strong structuration theory in accounting research.

\title{
REASON 3: DEVELOPING A MORE PROFESSIONAL APPROACH TO RESEARCH DESIGN
}

One of the acknowledged weaknesses of case study work using social theory is that the choice of theory tends to come after data collection. Whilst inductive approaches have a distinct place in research (Layder, 1999; Ahrens and Chapman, 2006), there is also a place for designing research with theory in mind. One danger for researchers is forcing theory and data together. There is a wider danger though, common to all social sciences where social theory is used interpretatively. Beart and da Silva (2011) propose that the representational or mirror approach to case study research, which maps out how empirical data illustrates a theory, or theory illustrates data, can only go so far before you run out of things to say. They alert researchers to the problem of ossification, of standing still, rather than generating new insights and new substantive theory (see also Mouzelis, 1995; 2008). This is observable in accounting research (Jack, 2017; Malmi and Granlund, 2009; Broadbent, 2012). Strong structuration theory offers a more dynamic approach, suited to abductive research (Lukka and Modell, 2010). Research projects can be designed in what might be termed a circular way (Makrygiannikis and Jack, 2016b; Wengraf, 2001), 
which means using theory in the design of data collection instruments, which allows data to be analysed with theory firmly in mind but in allowing departures from theory, surprises and deviations to become clear. Following up on these anomalies, which are not expected from the literature or prior experience, deepens the case study but then takes the researcher back to the theory. Perhaps the theory can be modified or supplemented with another theory, or by undertaking additional data collection. There may be the potential for new concepts to be added to the theory or new theoretical development that moves away from the original themes, based on new empirical data. In this way, not only is the analysis of data facilitated by ensuring that the right questions are being asked to elucidate knowledge that has a bearing on the research questions, but it also opens a more interrogative space in which to identify where data and theory do not fit easily, the spaces which need to be investigated more deeply.

In Stones' (2005) theory, research design falls out of the conceptual framework of agents' context and conduct analysis. The researcher must first identify the agent-in-focus, and the ontological level of abstraction at which they are working. For example, does the study involve of one or a few people in a very particular ontic setting (leading to micro-level analysis)? Is it a more floating study of people in an organisational or professional setting (meso-level)? Does it involve abstract notions of accounting (macro-level)? The researcher should identify the research problem in hand and look for the broad concepts that would help them to address that problem (see also Stones and Jack, 2016). Data collection was then be positioned in a way that addresses the problem-in-hand at an appropriate level of detail or abstraction.

Having identified the agent(s)-in-focus and the problem in hand, there are a number of recurrent steps (consistent with the notion of circular design). The researcher would look at:

a. Internal structures and conduct analysis

General dispositional frames of meaning for the agent-in-focus;

Conjuncturally-specific internal structures of the agent-in-focus;

External structures as perceived by the agent-in-focus.

b. Context analysis

Identify the relevant external structural clusters; position-practice relations; authority relations; material resources available.

The general dispositional and conjuncturally-specific frames of external agents.

c. dentify the possibilities open to the agent-in-focus, and the constraints placed upon them.

What impact might the agent-in-focus have on actual or predicted outcomes?

What judgements does the agent-in-focus make about active agency (to act routinely, to resist, to instigate change)? (Stones, 2005, pp.123-6)

So far, few studies have attempted this level of careful research design. Instead, they have tended to focus on only one or two elements of strong structuration theory. There is the potential for very rich data collection, with nuanced detail about how decisions were made, systems of control altered or why agents did or did not resist changes made to accounting rules and routines. Implicitly, we are still studying signification, legitimation and domination but are looking at the way agents use knowledge and communication of things when they choose how to act, and the consequences of those actions. Strong structuration theory provides lessons on how to take ontological concepts and use them to design research around specific actors and problems, in particular times and places. Stones has described the value of this approach by saying: 
the key aspect of structuration theory is that what's going on in the heads of people is never free-floating. It's always embedded in those contextual fields that we're looking at. Strong structuration theory takes more seriously the challenge of this for research practice, which, in turn, has required further development of the theory. (Stones and Jack, 2016, p.1149)

\section{CRITICISMS}

The key criticism of strong structuration theory in accounting is methodological and is built on concerns that it includes an element of dualism which departs from the duality and the 'flat and local' ontology of Giddens' theory (Englund and Gerdin, 2016). This echoes a long standing argument between critical realists such as Margaret Archer, and Giddens on whether duality is plausible (Stones, 2005; Parker, 2006 and others). In the end, Englund and Gerdin (2016) acknowledge that it is an ontological choice and the researcher must then conduct their research in ways that are consistent with that choice. In Stones (2005), the work by Archer, Mouzelis, Parker and others, and the issue of points of dualism or temporal distancing is addressed through the concept of external structures. Elsewhere, Stones (2001) has addressed the dualism/duality problem, proposing that in essentials, the differences between the two are subtle rather than entirely incompatible.

Criticisms of structuration theory in practice come from Roberts (2014), who doubts the ability of Giddens' theory to address the issue of agency, to accurately show the effects or lure of accounting on people and to address the issue of ethics (see also Englund and Gerdin, 2014). For Conrad (2014), it is the issue of relationships, which the work of Coad and Herbert (2009) and Coad and Glyptis (2014) begin to address, that is most underdeveloped in extant research, calling for work on more complex networks than those studied in Coad and Glyptis (2014). The other recurrent issue in structuration studies in management accounting is the ability of the theory to address questions of change rather than of stability. However, as yet, the potential of strong structuration theory to address all of these points has only just been touched upon.

\section{CURRENT LITERATURE}

The initial work by Jack and Kholeif (2008) and Coad and Herbert (2009) using strong structuration theory looked at specific aspects of the theory within the quadripartite nature of the structuration model. Jack and Kholeif (2008) examined a situation in which the different dispositions and conjuncturally-specific knowledge of clusters of actors militated against change, and the roles of management accountants, instead of becoming transformed into business partnerships by performance based budgeting returned to being a counting and reporting role. The context was the introduction of an enterprise resource planning system into the Industrial Modernisation Centre that was set up by the Egyptian Government using EU funding. The new system should have facilitated the use of a performance based budget system. In practice, the processes of structuration in play resulted in outcomes which reproduced the traditional role of a management accountant as cost information provider and did not allow a new 'business partner' type to become institutionalised. A lack of communication about what that new role and its practices would look like, or how it would be enacted, was central to understanding why the result was a compromised, if stable, system. Without effective communications in the form of guidelines, training, legislation and conversations regarding the new position-practices, there was no real active agency that could result in a change of internal or external structures. The notion of a new way of doing management 
accounting did not become part of the conjuncturally-specific knowledge of agents and so could not become, in time, part of their general disposition. No-one took action to change the rules and routines that needed to be changed and which would have indicated that the internal structures were changed. In fact, there were conflicts arising from the internal structures of different groups of agents, the different levels of knowledge and understanding each group had of the project, and their different perceptions of external structures and of each other. The identification of internal and external structures within the organisation, and the conditions of action surrounding focal agents, enabled the authors to unpack the complexities of this particular case.

Coad and Herbert (2009) looked at the concept of position-practices, concluding that'Our experience suggests that the analytical concept of position-practices helps focus researchers' attention on the relative power and strategic conduct of agents.'(Ibid., p.188). The notion of position-practices in relation to structuration came from Cohen (1989), one of Giddens' early adherents, whose work was nonetheless a critical development of structuration, which significantly influenced Stones' own developments. The use of position-practices was developed further by Coad and Glyptis (2014). They examined a joint venture between a state-owned oil company and a shipping management company in Greece with a fairly simple structure, in which the internal and external structures, and position-practices were relatively easy to define (Conrad, 2014). In terms of the accounting and control issues uncovered, they reported a situation in which:

the appropriation of profits by one party threatens the profitability of the other. The contradictions were reconciled through mutual accountability and complementary incentives built into the joint venture agreement, reflecting a dialectic of control, and forming the basis for system trust between the JV partners. (Coad and Glyptis, 2014, p.158).

Also, local practices of control (the use of the COSO framework, for example) were embedded into the joint venture, giving a degree of what Coad and Glyptis (2014) termed systems trust and a mode of operating as a opposed to a high degree of personal trust between participants (a situation they described as a truce in order that both sides could gain legitimation for their activities through the joint venture). This case in the Coad and Glyptis (2014) paper illustrates how structurationism allows for a very detailed and rich analysis of even apparently simple cases. Even in this case, there were multiple practices and relationships in play, and structurationism offered ways of analysis that were not centralised nor simplified into a single narrative. Because structuration theories hold 'the potential for providing multiple accounts of the practices of accounting and control' over periods of time and space, (Ibid., p.159) case study research has the potential to develop an understanding of the nuances of relationships and practices arising from the need for management control.

Given the closeness of these studies to the publication of Stones (2005), the analyses were developed from data already collected. In the case of Jack and Kholeif (2008), data had been collected based on a conceptual framework drawn from Giddens and then re-interpreted more effectively using the concepts of internal and external structures in strong structuration. Coad and Glyptis (2014), on the other hand, incorporated elements of position-practice into their research design. Manochin, Howell and Jack (2008), on the other hand, based their work on interview data that followed Stones' (2005) pattern (discussed under Reason 3 above) of exploring perceptions of the actors' own dispositions, situational knowledge and external structures. 
More recent papers, based on PhD research, have drawn on strong structuration theory at an early stage of research design and signs of more innovative approaches are emerging. For example, Feeney and Pierce (2016) examined new product development (NPD) in a small group manufacturing company from the viewpoint of six different agents-in-focus, each occupying different roles within the company but working to varying degrees with each other. The same process or story from six different viewpoints. Hence, the authors were able to explore how accounting was used and perceived by those creating and using the management accounting information generated in verbal and written forms by the NPD process. They chose to conceptualise accounting information as an external structure in the perception of the agents in focus: in other words, the interviewees saw accounting information as something that the organisation produced outside their own position-practices. What emerged was an understanding of the 'connecting tissue' between the internal structures and the active agency of different managers with each other and with the company. Concluding, Feeney and Pierce (2016, p. 1172) say that:

This understanding of the connecting tissue between structures was facilitated by the micro-analysis of six managers within a given conjuncture. Using the concept of the agent-in-focus as a tool with which to switch lenses from manager to manager acknowledged the web-like interdependencies between different processes of structuration. This allowed an exploration of the relationships between the various agents and structures.

In other words, structuration is not just one process or one set of rules and routines, norms and resource allocation within one organisation but outcomes come from a number of overlapping structuration processes. This is explored in a wider context by Moore and McPhail (2016) who explore social and environmental reporting as the outcome of structuration processes happening concurrently at different levels of analysis (local, national and international). There is scope for structuration studies to deal with quite complex situations through the motives, knowledge and actions of individuals within and across organisations.

Looking forward, a few researchers in the field, including myself, are building on the latest developments by Stones (2015) to explore ways of applying agents' context and conduct analyses more fully. Recognising that the central element of accounting is always recognised as communication (Coad et al, 2016, Jack, 2017), and following through the arguments given in Reason 2 above, such work would take communication as active agency as the key element. This would require the researcher to examine and map how agents-in-focus analyse their knowledge of a situation in acting, and their intentions to change the knowledge of networked others in ways that might change the internal structures of others and so influence outcomes.

The key is active agency, the act of communicating, not the item or medium of communication. The choice of argument or words or illustration, not just the existence of a report or KPI or email, say. One would have to elicit from data how a person or group of persons come to understand their situation and at what point they choose to deliberately influence a situation or others, and why. How do they assess the possibilities available to them; in which ways do they feel constrained; at what point do they choose to resist external or internal pressures? Often in accounting papers, there is significant detail about context, events and artefacts but little about the nature of the accounting taking place. Makrygiannikis and Jack (2016) observed subtle changes in the information required in budget reports, and in who was required to be involved in budgetary control and day-to-day accounting routines. These changes came about as managers' knowledge of their situation and of external structures in a financial crisis increased. With this knowledge, they adapted the budgetary system and monitoring requirements in hotels to communicate 
a different message: that high quality service should be maintained within strict controls on expenses and that budgetary processes actually played a vital role in the survival of the entity. These messages changed the knowledge and mind-sets of local managers as well (and the expectations of guests who had less choice but experienced the same high quality service in spite of the decreased facilities) leading to outcomes that changed the management accounting practices within that environment. This may be what Stones (2005) refers to as the fine brushstrokes of case study research, however it is important because it shows that strong structuration theory has the potential to address issues of agency, change and the nature of accounting.

As indicated above, Stones observed that in accounting 'precision matters and real knowledge matters', as does the question of whether agents choose to avoid precision and increase obfuscation in accounting communications (Stones and Jack, 2016, p.1150). What is accounting knowledge? What is being communicated to whom? and why, when, and how is it received? are fundamental questions in accounting research. Strong structuration theory offers a set of ontological and conceptual tools with which to bridge the divide between theory and empirical research (Coad et al, 2016; Stones and Jack, 2016). Most importantly, it offers possibilities to research accounting from the viewpoint of the people involved: not analysing simply their roles and actions, but their understanding and reading of situations. From this we begin to understand why people act in the way that they do, and create particular outcomes. People and how they talk, write and think about accounting and the role of being an accountant are less evident in accounting research than might be expected (Jack, 2017). Bringing people and accounting calculations and other communications back into focus through strong structuration theory or other purposefully designed interpretative research, helps to address Hopwood's $(2007$, p.1373) concern that:

accounting is currently left with a research community whose members are, in my view, too conservative, too intellectually constrained, too conformist, and insufficiently excited by and involved with the changing practice or regulation of the craft

Putting accounting communication as active agency at the heart of our research in management accounting offers research that is exciting and interesting to those in other disciplines and in practice, as well as stimulating our own discipline.

\section{REFERENCES}

Ahrens, T., \& Chapman, C. S. (2006). Doing qualitative field research in management accounting: Positioning data to contribute to theory. Accounting, Organizations and Society, 31(8), 819-841.

Baert, P. (2010). Social theory in the twentieth century. Maiden, MA: Polity Press.

Baxter, J., \& Chua, W. F. (2003). Alternative management accounting research—whence and whither. Accounting, organizations and society, 28(2), 97-126.

Berger, P. L., \& Luckmann, T. (1991). The social construction of reality: A treatise in the sociology of knowledge. London: Penguin.

Broadbent, J. (2012). Commentary on Parker: Groundhog day and optimism. Critical Perspectives on Accounting, 23(1), 71-77.

Bryant, C.G.A., \& Jary, D. (2011). Anthony Giddens, in Ritzer, G. \& Stepnisky, J. (Eds.) The Wiley-Blackwell companion to major social theorists. Malden: Wiley-Blackwell. 
Coad, A., Jack, L., \& Kholeif, A. (2016). Strong structuration theory in accounting research. Accounting, Auditing \& Accountability Journal, 29(7), $1138-1144$.

Coad, A.F., \& Glyptis, L.G. (2014). Structuration: a position-practice perspective and an illustrative study. Critical Perspectives on Accounting, 25, 142-161.

Coad, A.F., \& Herbert, I.P. (2009). Back to the future: new potential for structuration theory in management accounting research? Management Accounting Research, 20, 177-192.

Cohen, I.J. (1989). Structuration Theory: Anthony Giddens and the Constitution of Social Life. London: Macmillan.

Conrad, L. (2014). Reflections on the application of and potential for structuration theory in accounting research. Critical Perspectives on Accounting, 25 (2), 128-134

Englund, H., \& Gerdin, J. (2016). What can (not) a flat and local structuration ontology do for management accounting research? A comment on Coad, Jack and Kholeif. Qualitative Research in Accounting \& Management, 13(2), 252-263.

Englund, H., \& Gerdin, J. (2014). Structuration Theory in Accounting Research: Applications and accountability. Critical Perspectives on Accounting, 25(2,), 162-180.

Englund, H., Gerdin, J. and Burns, J. (2011). 25 years of Giddens in accounting research: achievements, limitations and the future. Accounting, Organizations and Society, 36, 494-513.

Feeney, O. and Peirce, B. (2016). Strong structuration theory and accounting information: an empirical study. Accounting, Auditing and Accountability Journal, 29(7), 1152-76.

Giddens, A. (1984) The constitution of society, Cambridge: Polity Press.

Hopwood, A.G. (2007). Whither Accounting Research? The Accounting Review, 82, 1365-1374.

Hopwood, A. G., \& Miller, P. (1994). Accounting as social and institutional practice. Cambridge: Cambridge University Press.

Jack, L. (2017), Accounting and social theory: an introduction. Abingdon: Routledge.

Jack, L. (2013), Accounting communications inside organisations, in Jack, L., Davidson, J. and Craig, R., Editors, The Routledge Companion to Accounting Communication, Abingdon: Routledge.

Jack, L., \& Kholeif, A. (2008). Enterprise resource planning and a contest to limit the role of management accountants: a strong structuration perspective. Accounting Forum 32(1), 30-45.

Lukka, K., \& Modell, S. (2010). Validation in interpretive management accounting research. Accounting, Organizations and Society, 35(4), 462-477.

Makrygiannikis, G. and Jack, L. (2016), Understanding management accounting change using strong structuration frameworks, Accounting, Auditing and Accountability Journal, 29(7), 1234-1256. 
Malmi, T., \& Granlund, M. (2009). In search of management accounting theory. European Accounting Review, 18(3), 597-620.

Manochin, M. M., Jack, L., \& Howell, C. (2008). The boundaries of reporting sustainable development in social housing. Public money and management, 28(6), 345-352.

Mattessich, R. (2007). Two hundred years of accounting research. Abingdon: Routledge.

Moore, D.R.J., \& McPhail, K. (2016). Strong structuration and carbon accounting: A position-practice perspective of policy development at the macro, industry and organizational levels. Accounting, Auditing \& Accountability Journal, 29(7), $1204-1233$.

Mouzelis, N. P. (2008). Modern and postmodern social theorizing: Bridging the divide. Cambridge: Cambridge University Press.

Mouzelis, N.P. (1995). Sociological theory: what went wrong?: diagnosis and remedies. London: Routledge.

Parker, J. (2006), "Structuration's future? From 'all and everywhere' to 'who did what, where, when, how and why?"', Journal of Critical Realism, Vol. 5, 122-138.

Parker, J. (2000). Structuration. London: Open University Press.

Ritzer, G. (2007). Contemporary sociological theory and its classical roots: the basics, 2nd edition. New York: McGraw-Hill.

Roberts, J. (2014). Testing the limits of structuration theory in accounting research. Critical Perspectives on Accounting, 25(2), 135-141.

Roberts, J., and Scapens, R.W. (1985). Accounting systems and systems of accounting: understanding accounting practices in their organizational contexts. Accounting, Organizations and Society, 10, 443-456

Stones, R. (2015), Why current affairs needs social theory, Palgrave Macmillan, Basingstoke.

Stones, R. (2005), Structuration theory, Palgrave Macmillan, Basingstoke.

Stones, R. (2001). Refusing the realism—structuration divide. European journal of social theory, 4(2), 177-197.

Stones, R. (1996) Sociological Reasoning: towards a past-modern sociology, Palgrave Macmillan, Basingstoke.

Stones, R. and Jack, L.(2016. The bridge between ontological concepts and empirical evidence: an interview with Rob Stones, Accounting, Auditing \& Accountability Journal, Vol. 29 Iss: 7, pp.1145 - 1151

Wengraf, T. (2001). Qualitative research interviewing: Biographic narrative and semi-structured methods, London: Sage Publications. 